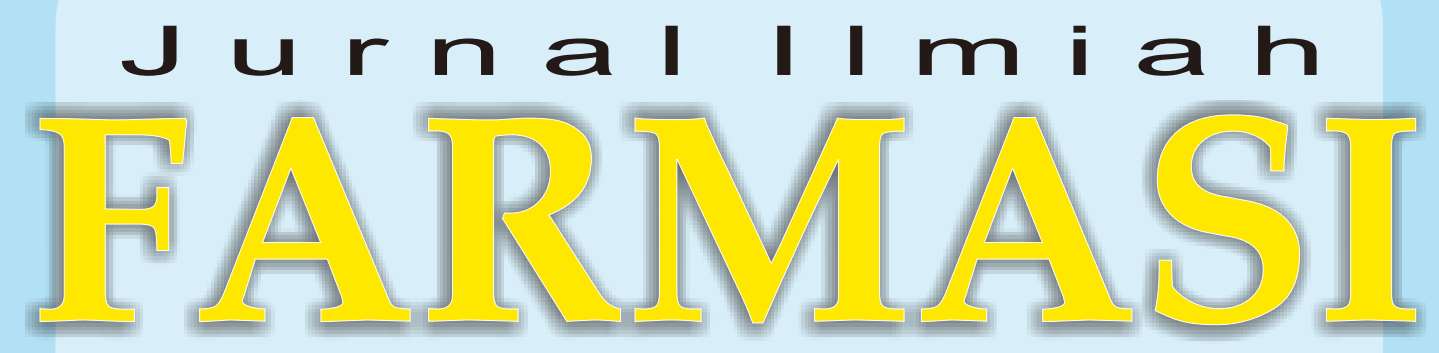

(Scientific Journal of Pharmacy) 
JURNAL ILMIAH FARMASI

(SCIENTIFIC JOURNAL OF PHARMACY)

PIMPINAN UMUM/ PENANGGUNG JAWAB

Dekan Fakultas Matematika dan Ilmu Pengetahuan Alam

Universitas Islam Indonesia

WAKIL PIMPINAN UMUM/ WAKIL PENANGGUNG JAWAB

Ketua Jurusan Farmasi FMIPA UII

\section{MITRA BESTARI}

1. Prof. Dr. Wiryatun Lestariana, Apt

2. Prof. Dr. Zullies Ikawati, Apt

3. Prof. Dr. Sudibyo Martono, Apt

4. Dr. Tedjo Yuwono, Apt

5. Prof. Dr. Dachriyanus, Apt

6. Prof. dr. Iwan Dwiprahasto, MMedSc, PhD

7. Prof. Dr. Lukman Hakim M.Sc., Apt

8. Prof. Dr. Achmad Fudholi, DEA, Apt

9. Prof. Dr. Ibnu Gholib Gandjar, DEA., Apt

\begin{tabular}{ll} 
& \multicolumn{1}{c}{ DEWAN EDITOR } \\
Ketua & : Saepudin, M.Si., Apt \\
Sekretaris & : Rochmy Istikharah, M.Sc., Apt. \\
Anggota & : Vitarani Dwi Ananda Ningrum, M.Si., Apt \\
& Okti R. Mafruhah, MSc., Apt \\
& Dimas Adhi Pradana, MSc., Apt. \\
& Fithria DA. Suryanegara, MSc., Apt. \\
& Ari Wibowo, S.Farm., Apt \\
& Arba Pramudita Ramadani, MSc., Apt. \\
& Oktavia Indrati, S.Farm., Apt.
\end{tabular}

Penerbit

Jurusan Farmasi Fakultas Matematika dan IImu Pengetahuan Alam Universitas Islam Indonesia

Alamat Penerbit Jurusan Farmasi FMIPA UII

Jl. Kaliurang Km. 14,4 Yogyakarta 55584

Telp. (0274) 896439 ext. 3047

Email: jif@uii.ac.id 


\title{
UJI KEPEKAAN BAKTERI Escherichia coli HASIL ISOLASI DARI URIN PASIEN RUMAH SAKIT Dr. Sardjito TERHADAP ANTIBIOTIK GOLONGAN $\beta$-LAKTAM
}

\author{
Sri harnanik *) Sri Mulyaningsih *) Asih Triastuti *) \\ *) Jurusan Farmasi, FMIPA UII
}

\begin{abstract}
Uncontrolled use of antibiotic caused the emergence of bacteria strain resistant toward of antibiotic. The sensitivity assay of $E$. coli toward $\beta$-lactam antibiotic has been done. The sensitivity assay was started with isolated bacteria from patients urine at Dr. Sardjito hospital followed by count total of colony/number of germ which growth and identified the bacteria. The Kirby Bauer method was performed. Antibiotic impregnated disk (ampicillin $30 \mu \mathrm{g}$, sulbactam/ampicillin $20 \mu \mathrm{g}$, cefotaxim $30 \mu \mathrm{g}$, ceftazidime $30 \mu \mathrm{g}$, ceftriaxon $30 \mu \mathrm{g}$, cefpirom $30 \mu \mathrm{g}$, cefepim $30 \mu \mathrm{g}$ and imipenem $10 \mu \mathrm{g}$ ) were placed on agar plate previously streaked with suspension of $E$. coli $\left(1.10^{8} \mathrm{CFU} / \mathrm{ml}\right)$. The plates were incubated for $18-24$ hours at $37^{\circ} \mathrm{C}$. The diameters of the zone inhibition were measured, and compared to standar interpretive zone sizes. The result of the study showed that all of $E$. coli resistant toward antibiotic ampicillin; $65 \%$ resistant toward antibiotic sulbactam/ampicillin; $50 \%$ still sensitive toward antibiotic third cefalosporin generation that is cefotaxim, ceftazidime, ceftriaxon; more than $50 \%$ sensitive toward fourth cefalosporin generation like cefepim, cefpirom and all of pathogen bacteria $E$. coli sensitive toward antibiotic imipenem.
\end{abstract}

Key Words : E. coli, $\beta$-lactam antibiotic, Sensitivity assay, Urine of patient hospital. 